\title{
INNOVATIVE AND PRIZE-WINNING EDUCATIONAL MUSIC ACTIVITIES IN SPECIAL EDUCATION THOUGHT THE ETWINNING PROJECT
}

\author{
Theodoros Tsampatzidis ${ }^{\mathrm{i}}$ \\ MA, Teacher of Music Education, \\ Thessaloniki Music School, \\ Doctoral Candidate, \\ Department of Music Studies, \\ Ionian University, \\ Greece
}

\begin{abstract}
:
The Thessaloniki Music School has been repeatedly awarded for its innovative activities in eTwinning programs in special music education. Students with visual impairments and with developmental disorders were encouraged to participate in these programs. Digital music was exchanged from many European countries and original musical compositions were produced and presented. The European and traditional music scores were presented for the first time in electronic Braille form. For students with learning difficulties and pervasive developmental disorders there were special educational presentations with a combination of special educational methods, Relationship Development Intervention, the Irlen method using light sensitivity, and Treatment and Education of Autistic and Communication Handicapped Children (TEACCH method). The greatest achievement of the project was the composition of the e Twinning hymn whose lyrics are about friendship in various musical arrangements and languages. Our hymn was presented at concerts, conferences, the Grundtvig European workshop and was uploaded on websites.
\end{abstract}

Keywords: special needs and music education, innovation and music education, Braille music, Byzantine chant Braille code, eTwinning

\section{Introduction}

Etwinning (https://www.etwinning.net) is the community for schools in Europe that offers a platform for staff (teachers, head teachers, librarians, etc.), working in a school in one of the European countries involved, to communicate, collaborate, develop projects, share and, in short, feel and be part of the most exciting learning community in Europe.

${ }^{i}$ Correspondence: email brailletheo@gmail.com 
Etwinning is co-funded by the Erasmus+, the European program for Education, Training, Youth and Sport. Etwinning promotes school collaboration through the use of ICT in order to allow schools to easily form short or long term international projects in any subject area.

I have been working with eTwinning projects since 2007. My projects have to do with pupils with learning difficulties and special needs. The first eTwinning project that we created was an eTwinning Music Library. I started teaching music to students who are visually impaired at the Music High School of Thessaloniki offering an individual educational program for these students. I have been using innovative actions and Information and Communication Technologies (ICT) in order to transcribe all kind of music to Braille using computer. I developed an electronic Braille code based on the Chryssafides method for the electronic transcription of Byzantine music and traditional Greek music, where each music tone corresponds to a combination of Latin letters-codes so that music can be printed with an embosser and read by visually impaired pupils.

This was the first time in Greece that users with impaired vision could access and use braille music archives through the e Twinning project and its website. An electronic code was devised and used to transcribe European and traditional Greek and Byzantine music to an electronic braille form, so that they could be uploaded to the digital library of this project. The project was awarded the National Prize for e Twinning in 2009 and an award for Excellence and Innovation in education in 2010 (Tsampatzidis, 2012).

The project started off in the Scuola Secondaria di 1 grado ad indirizzo musicale A. Lamarmora and N. Canelles in Italy, directed by the English teacher Susanna Pizzati and in the Thessaloniki Music School directed by music teacher Father Theodoros Tsampatzidis. Two other schools joined the project later, the Scuola Primaria D'Onofrio from Italy and the Southwater Infant School from the UK. This project was also combined with information from participation in an e Twinning seminar with access for students with impaired vision organized by the Macedonia University Library. The students did research on transcribing the music into braille (Kersten, 1977; Braille Authority of North America, 2016). A concert with works by Greek and Italian composers performed by school students marked the beginning of the project. Blind students took part.

The students also asked if they could present Christmas carols on Skype, and though it started with a small group of students, it ended up a huge collaboration of music teachers, information technology teachers, art and foreign language teachers, choirs and ensembles with both traditional and contemporary music.

The basic core of the project was the use of New Technologies. The library used Twinspace platform of eTwinning to upload material. We used Finalle and Sibelius to transcribe sheet music. Cool edit was used for sound recording and editing in $\mathrm{mp} 3$ and midi, CD extractor to transcribe sound archives. We used Winbraille, Jaws, and Supernova for students with visual impairment. Additionally, a special electronic code was devised and used to transfer traditional and European music texts to the form of an electronic braille text. 
It is also noteworthy that the students with special educational needs who took part learned to use Twinspace to have access to musical archives which they and their fellow students created and they became familiar with the function of an electronic data base and the structure of its three levels.

\section{Electronic Code for the Transfer Byzantine Chant to Braille}

In the field of classical and modern music, there are Braille symbols that define every detail, such as pitch, values, metric rhythm, alternation of musical keys, changing dynamics, color and expression, repetition, musical ornaments and instructions: for example, which finger will play which note on the piano, the consensus by the contrapuntal polyphonic, how to transcribe instrumental or vocal music, etc. (Jenkins, 1960).

Byzantine Music is the common term for post-Byzantine liturgical chant. Byzantine chant is the traditional music of the Eastern Orthodox Church. It boasts an uninterrupted history that stems from the chant dialects of the ancient eucharistic communities throughout the Christian world. Over the centuries, it evolved naturally and within specific traditional parameters, and was continuously refined by the Church. Byzantine music was systematized primarily by St. John Damascene in the eighth century, and St. John Koukouzelis, who lived in the fourteenth century (Chaldeakes, 2012).

The first big step in teaching the Art of Chanting using the Braille system was with the adoption of the Demetrios Chryssafides teaching method. Demetrios Chrissafides was a blind Greek chanter and Byzantine chant teacher. He was born in Rogous, Kalavryta in 1905. He studied Byzantine music and graduated in 1932. He worked as a Chanter in various churches in Athens and as teacher professor of Byzantine music at the House for the Blind in Kallithea. When the House of the Blind was established in Athens in the beginning of the twentieth century, the teachers associated letters of the braille alphabet with letters of the Greek alphabet and taught this to the blind students. The students also learned the braille music notation used in Western Europe. Although this notation enabled them to transcribe music written in staff notation into braille, they had no way of transcribing music written in Byzantine notation, which is the primary method for writing ecclesiastical music in Greece. Demetrios Chryssafidis was the first who tried to solve the problem by converting Byzantine music melodies first into staff notation and then into the braille music notation of Western Europe. With the help of Constantinos Papademetriou he transcribed hymns of Byzantine music into European staff notation in braille and began teaching this method to blind chanters. Many blind chanters and students become acquainted with this method. He created a writing system for Byzantine music for the blind, which was approved by the Holy Synod of the Church of Greece in 1931. This system was included in the International Braille code in 1995.

This method of writing music seemed quite easy to those that living in the House of the Blind, since it did not require that they learn another notation in addition to the 
European braille music notation that was already being taught. Chryssafides worked as the teacher of Byzantine music at the House of the Blind for many years. He equated a one-beat note on Nee with a quarter note on Do. According to the Chryssafides method the chanting part is transferred in correspondence with European music into Braille music notation using six dotted codes.

The next table (Figure 1) shows the Greek language character symbols according to the electronic braille code (Figure 1).

\begin{tabular}{|c|c|c|c|c|c|c|c|c|c|c|c|}
\hline $\mathrm{A}$ & $\mathrm{B}$ & $\Gamma$ & $\Delta$ & $\mathrm{E}$ & $\mathrm{Z}$ & $\mathrm{H}$ & $\Theta$ & $\mathrm{I}$ & $\mathrm{K}$ & $\Lambda$ & $\mathrm{M}$ \\
\hline $\mathrm{a}$ & $\mathrm{b}$ & $\mathrm{g}$ & $\mathrm{d}$ & $\mathrm{e}$ & $\mathrm{z}$ & $>$ & $?$ & $\mathrm{i}$ & $\mathrm{k}$ & $\mathrm{l}$ & $\mathrm{m}$ \\
\hline $\mathrm{N}$ & $\mathrm{\Xi}$ & $\mathrm{O}$ & $\mathrm{\Pi}$ & $\mathrm{P}$ & $\mathrm{\Sigma}$ & $\mathrm{T}$ & $\Upsilon$ & $\Phi$ & $\mathrm{X}$ & $\Psi$ & $\Omega$ \\
\hline $\mathrm{n}$ & $\mathrm{x}$ & $\mathrm{o}$ & $\mathrm{p}$ & $\mathrm{r}$ & $\mathrm{s}$ & $\mathrm{t}$ & $\mathrm{y}$ & $\mathrm{f}$ & $\mathrm{h}$ & $\&$ & $\mathrm{j}$ \\
\hline $\mathrm{AI}$ & $\mathrm{EI}$ & $\mathrm{OI}$ & $\mathrm{A} \Upsilon$ & $\mathrm{E} \Upsilon$ & $\mathrm{O} \Upsilon$ & $\mathrm{HI}$ & $\Upsilon \mathrm{I}$ & $\cdot$ & $;$ & $!$ & $\begin{array}{c}\text { Capital } \\
\text { character } \\
\text { sign }\end{array}$ \\
\hline$<$ & $\%$ & {[} & $*$ & $:$ & $\mathrm{u}$ & $\backslash$ & $\mathrm{l}$ & 4 & 5 & 6 &. \\
\hline
\end{tabular}

Figure 1: Greek language character symbols according to the electronic braille code

The next table (Figure 2) shows the basic Byzantine Braille music electronic symbols according to the Chryssafides method:

\begin{tabular}{|l|c|c|c|c|c|c|c|c|}
\hline $\begin{array}{l}\text { Byzantine chant } \\
\text { music characters }\end{array}$ & Nee & Pa & Vu & Ga & Di & Ke & Zo & Rest \\
\hline Notes & DO & RE & MI & FA & SOL & LA & SI & Rest \\
\hline $\begin{array}{l}4 \text { crotchets } \\
\begin{array}{l}\text { Semibreve whole note } \\
\text { or } 1 / 4 \text { of a crotchet } \\
\text { Semiquaver sixteenth } \\
\text { note }\end{array}\end{array}$ & $\mathrm{Y}$ & $\mathrm{Z}$ & $\&$ & $=$ & ( & ! & ) & $\mathrm{M}$ \\
\hline $\begin{array}{l}\text { 2 crotchets } \\
\text { Minim half note }\end{array}$ & $\mathrm{N}$ & $\mathrm{O}$ & $\mathrm{P}$ & $\mathrm{Q}$ & $\mathrm{R}$ & $\mathrm{S}$ & $\mathrm{T}$ & $\mathrm{U}$ \\
\hline $\begin{array}{l}\text { Crotchet } \\
\text { quarter note }\end{array}$ & $?$ & $:$ & $\$$ & ] & I & [ & $\mathrm{W}$ & $\mathrm{V}$ \\
\hline $\begin{array}{l}\text { 1/2 of a crotchet } \\
\text { Quaver eighth note }\end{array}$ & $\mathrm{D}$ & $\mathrm{E}$ & $\mathrm{F}$ & $\mathrm{G}$ & $\mathrm{H}$ & $\mathrm{I}$ & $\mathrm{J}$ & $\mathrm{X}$ \\
\hline
\end{tabular}

Figure 2: Byzantine chant electronic symbols notation according to Chryssafides method

Byzantine notation contains several qualitative symbols that describe how a particular note or group of notes should be chanted. The basic qualitative Byzantine chant symbols are omalon, antikenoma, vareia, psyphiston, omalon, syndesmos, and endofonon.

The omalon adds a ripple to the neume it is written with. In Byzantine Music notation for the sighted it is placed beneath the neume it affects, whereas in Braille Byzantine Chryssafides notation it is written before the neume it affects. 
The antikenoma adds a brief shake to the neume it is written with. In Byzantine Music notation for the sighted, it is placed beneath the affected neume, but in Braille Byzantine Music notation, it is written after the neume it affects.

The syndesmos, also named eteron, is used to link two notes together and also place a flutter on the first of the two.

The vareia is placed before the neume it affects and is used to accentuate a neume, although it frequently has a quantitative interpretation.

The psefiston is also used to accentuate a neume. In Byzantine Music notation for the sighted, it is placed beneath the affected neume, but in Braille Byzantine Music notation, it is written before the neume it affects.

The endofonon symbol indicates that a neume is sung through the nose with the mouth closed. It is so rare that many theory books of Byzantine Music don't mention it. In Braille Byzantine Music notation, it is written before the neume it affects.

Chryssafides used 6-dot special notes for these qualitative Byzantine chant symbols (Figure 3):

\begin{tabular}{|c|c|c|c|c|c|}
\hline Antikenoma & Vareia & Psefiston & Omalon & Syndesmos & Endophonon \\
\hline 4 & 7 & 6 & 0 & $\mathrm{C}$ & 5 \\
\hline
\end{tabular}

Figure 3: Qualitative signs - Byzantine chant electronic

Braille symbols according to the Chryssafides method

The petaste Byzantine chant character is used to ascend one note with a flutter of the voice. The manner in which this flutter is executed can depend on context. The performance of petasti where a basic ascending and intonation sign is also noted 8 (dots 236) in Chryssafides' method.

Also, codes are given when necessary to determine the transfer of part into ypatoeidi (low), nitoeidi (high) and the mesoidi (medium) voice area (Figure 4).

\begin{tabular}{|c|c|c|}
\hline Medium voice area & High voice area & Low voice area \\
\hline$\wedge$ & $\wedge$ &, \\
\hline
\end{tabular}

Figure 4: Voice area - Byzantine chant electronic Braille symbols according to the Chryssafides method

A modulant is a symbol that affects the pitch of more than one note in the scale. There are two kinds of modulants: hroas and fthoras. The difference between them is that a hroa affects the pitch of only a few notes, whereas a fthora affects the entire scale. In Byzantine Music there are eight modes - scales: First (A mode), Second (B mode) ,Third (C mode), Fourth (D mode), plagal A mode, plagal B mode, Varis, and plagal D mode. There are eight diatonic fthoras, four chromatic fthoras and one enarmonic fthora. Chrissafides used 6dot signs for all these modulants.

The following table shows the Braille signs for all the fthoras (Figure 5): 
IN SPECIAL EDUCATION THOUGHT THE ETWINNING PROJECT

\begin{tabular}{|l|l|l|l|l|l|l|l|l|}
\hline \hline & Ni & Pa & Vu & Ga & Di & Ke & Zo & Ni \\
\hline Diatonic fthores & $\#$ & L & - & $*$ &. & $\mathrm{~K}$ & $/$ & + \\
\hline Chromatic fthores of B mode & & & &.$k$ & $\_k$ & & & \\
\hline Chromatic fphores of plagal B mode & & -1 & & & .1 & & & \\
\hline Enarmonic fthora & & & & & & & $>$ & \\
\hline
\end{tabular}

Figure 5: Modulants-Fthoras- Byzantine chant electronic

Braille symbols according to the Chryssafides method

Using hroas the melodic distances between the notes change according to each hroa. They are three special hroas: zygos, kliton and spathi.

The following table (Figure 6) shows the signs for these three hroes:

\begin{tabular}{|c|c|c|}
\hline Zygos & Kliton & Spathi \\
\hline$-\#$ & ${ }_{-}^{+}$ & $>$ \\
\hline
\end{tabular}

Figure 6: Hroas - Byzantine chant electronic Braille

symbols according to the Chryssafides method

Accidentals (i.e., sharps and flats) change the pitch of a single note. In Byzantine Music, sharps and flats affect only one note rather than all following instances of that note, which is what sharps and flats do in Western music. An exception to this is the "permanent sharp" and the "permanent flat" of Byzantine Music notation. These two symbols are almost never used except in third mode.

According to Chryssafides' method, the accidental signs are shown on the following table (Figure 7):

\begin{tabular}{|c|c|c|c|}
\hline $\begin{array}{c}\text { Diesis- } \\
\text { (Sharp sign) }\end{array}$ & $\begin{array}{c}\text { Hyfesis } \\
\text { (flat sign) }\end{array}$ & $\begin{array}{c}\text { Geniki diesis } \\
\text { (Permanent sharp) }\end{array}$ & $\begin{array}{c}\text { Geniki Hyfesis } \\
\text { (Permanent flat) }\end{array}$ \\
\hline$\%$ & $<$ & $-^{*}$ & $\ldots$ \\
\hline
\end{tabular}

Figure 7: Accidental- Byzantine chant electronic Braille

symbols according to the Chryssafides method

The hymnological text is cited along with the music in Braille music notation and a dash is placed between them called a hyphen.

The following figure shows an example of transcribing Byzantine chant to electronic Braille format using the Chryssafides method. In Figure 8, a Kekragarion hymn in modus A in visual score is presented (Figure 8). 
Hxos $\frac{\mathrm{a}}{\mathrm{q}} \mathbf{\mathrm { N }}$

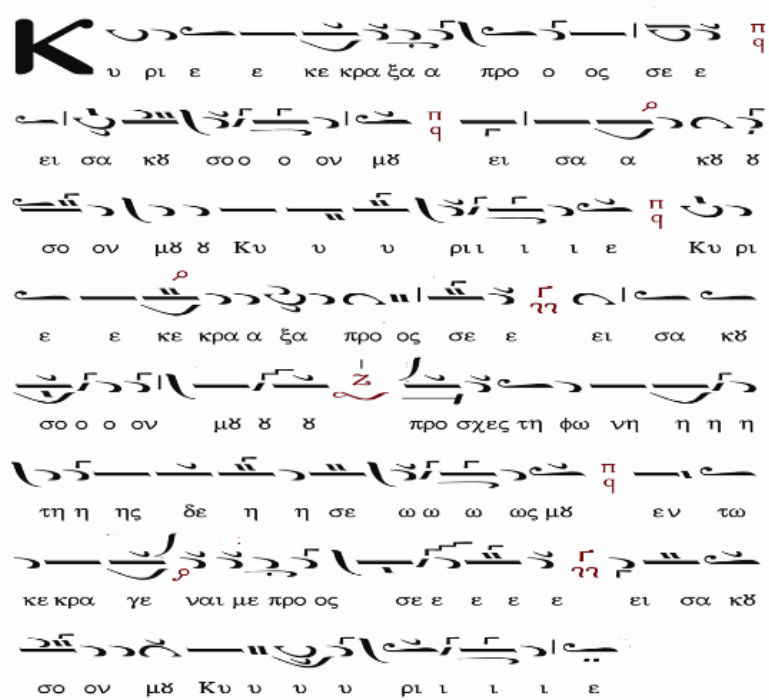

Figure 8: Byzantine Kekragarion hymn in modus A (Visual score)

The following figure shows the same Byzantine hymn in Braille format using the Chryssafides method (Figure 9).

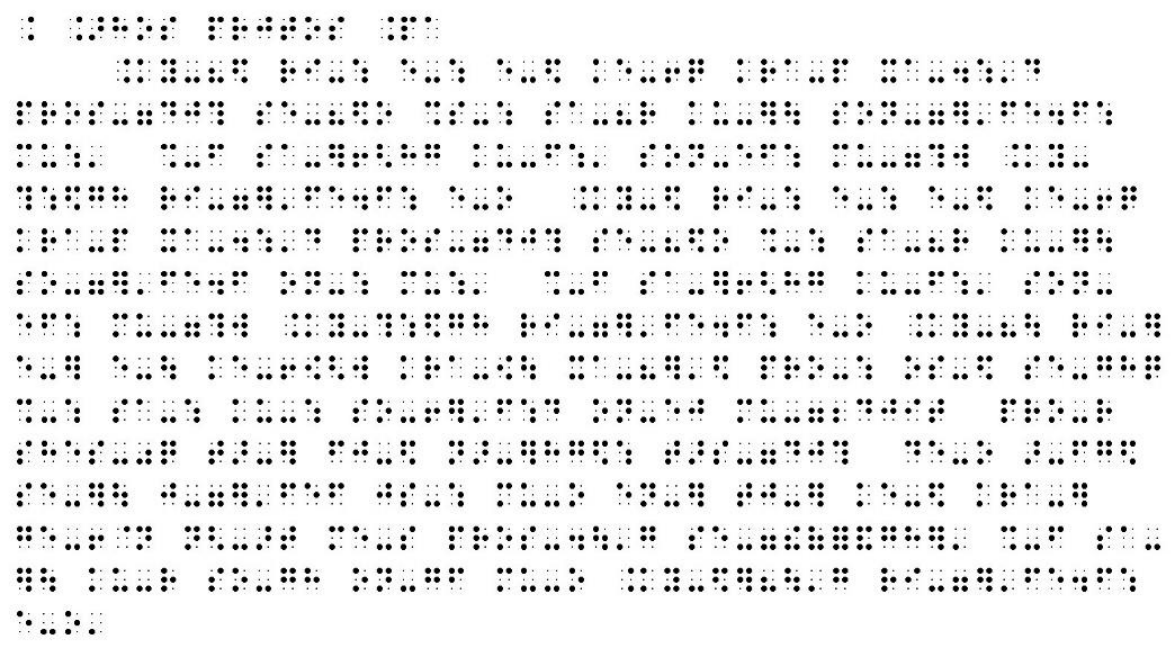

Figure 9: Byzantine Kekragarion hymn in modus A (Braille format using the Chryssafides method)

The following figure shows the same Byzantine hymn in Electronic Braille Byzantine Format using the Chryssafides method (Figure 10). 
.>hos prjtos .pa.

.ky-8\$ ri-: e-: e-\$ ke-6q kra-p xa-4:'d pros-7dj? se-8\$o \%s-: sa-8r ku-] son-7]'fe4f: mu:' \%f sa-]6<hg ku-f:' son-ef: mu-7?w .ky-?:\$gh ri-7]'fe4f: e-o .ky-8 \ri-] e-] e- $\backslash$ ke-6[<w kra-[ $\backslash$ xa-8]'\$ pro-: os-\$ se-ghq \%-: sa-: ku-: so-6]'f:d on-ej mu-72djit pro-r shes-0q $t>-]$ fj-\$ n>]hg\$: $t>s-7 d j$ ? de-o >-fg\$ se-] $\backslash$ j-7]'fef js-: mu-o en-] tj-] ke-\$ kra-] ge-6@n n<->t me-s pros-4 \'g se-7!(=\&gh]' \%-f sa-] $\backslash$ ku-r so-gh on-gf mu-o .ky-\$]8 'g ri-7]'fe4f: e-o'

Figure 10: Byzantine Kekragarion hymn in modus A (Electronic Braille format using the Chryssafides method)

Apart from Chryssafides' method of transferring Byzantine chant music notation into the Braille system; there is Father Dossitheus' method. His name as a layman was Pantelis Paraskevaidis. In 1929 he went to the Holy Mountain, where he became a monk and was given the name Dositheos. Dositheos approached the issue of writing Byzantine music in braille differently from Chryssafides. According to this method all the Byzantine music characters are transferred separately and directly to the Braille system without any connection with the worldwide international Braille music code (Figure 11).
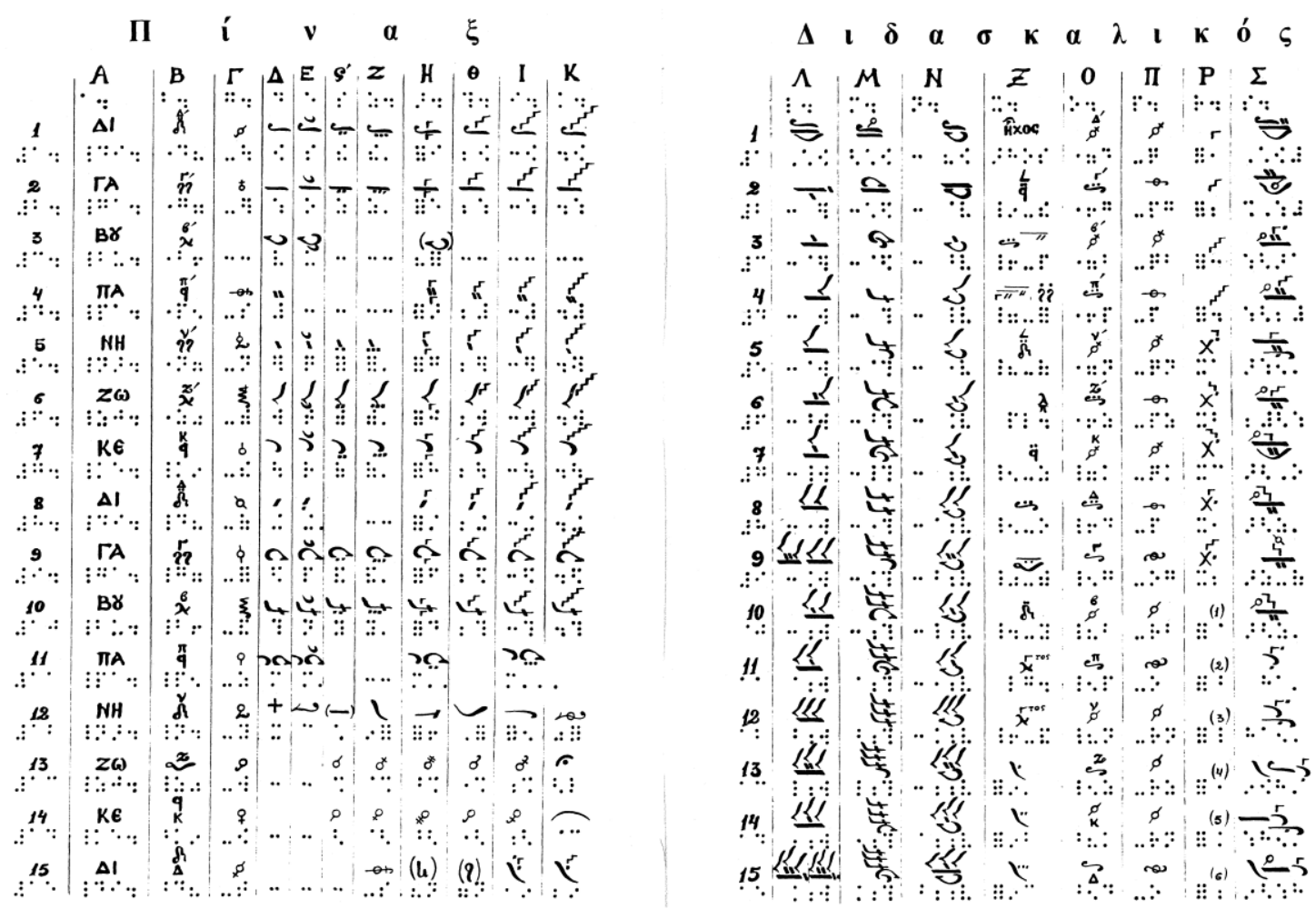

Figure 11: Chart of all the 6dot Braille symbols of Byzantine Notation according to Fr Dositheus method

Many blind chanters, who had already begun using Chryssafidis' system claimed that the Dossitheus method was difficult and impractical. There is also a negative point 
about Dossitheus. He left Mount Athos without permission and went to Athens. He published some books but the publication rights according to the Mount Athos Community rules belong there and not to the Monastery of Agia Skepi Keratea (Agios Kyprianos) who published his books.

Father Dositheos helped establish the Association of Blind Chanters in Athens and wrote hundreds of pages of his own compositions of Byzantine music, which were later transcribed into standard Byzantine notation for the sighted and published from the Holy Monastery of St Antony in Arizona (http://music.stanthonysmonastery.org).

The possibility of transferring Byzantine music to the Braille system was announced at the first International Conference of the Music Department at the University of Macedonia- "Byzantine Music in the 21st century, problems and possibilities" (Tsampatzidis, 2007).

The use of the electronic braille code has many advantages. It is like the difference between using a typewriter and using a computer. The volume of a braille music book is usually five times the size of a book for people who can see, while an electronic book only uses a few kilobytes and can be transferred to a USB stick. In this way there is a significant economy in size and you can even note down every detail using the electronic code about the performance of the music.

Students with impaired vision from European programs and from all over the world, using this system on the internet, can access the chanting technique. They can access musical archives, communicate and work on music together without using printed handouts. These great innovations are indicative of our level of cultural education, and it all started with Louis Braille two hundred years ago, who proved to the world that disability cannot stop you if you really want to achieve something.

Disabilities can even motivate people to achieve great things. This project was the catalyst for the beginning of a multidimensional music library in which many schools participated, concentrating on digital films made as group projects.

\section{3. eTwinning Music Library}

The objectives of this project are the creation of a digital European music library with access for students with specific learning difficulties, the production and presentation of original musical material for use in school celebrations and events and the active and creative participation and co-education of students with learning disorders in an interdisciplinary context with music at its center. The students created multilingual music presentations using Power Point, which contains music compositions, paintings, musical scores and drawings. The Digital Music Library is enhanced by the production of digital educational films. A presentation of our project was given in an official ceremonymeeting in Italy, which was organised by the Municipality of Ferrandina (Figure 12). 


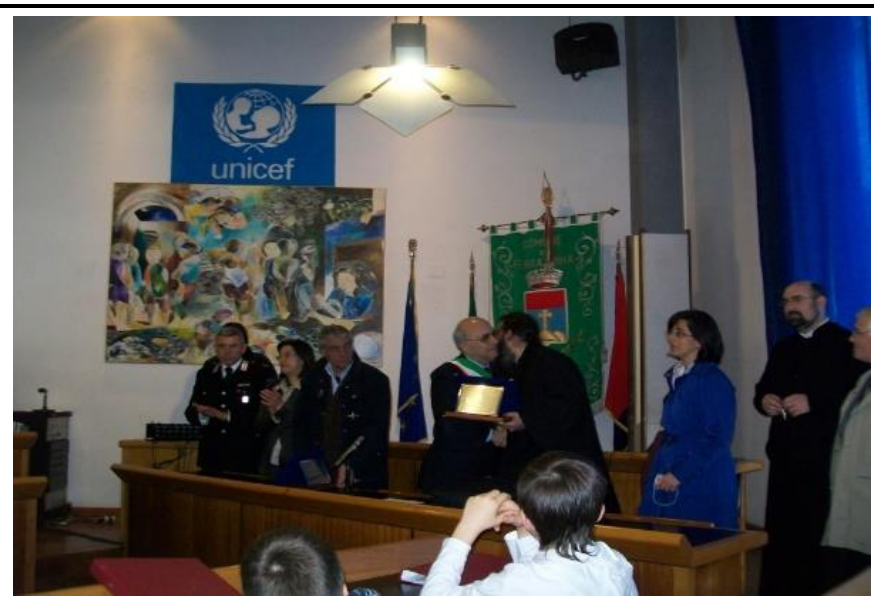

Figure 12: Etwinning Digital Music Library project, awarded in Ferrandina, Italy 2010

The results of the applications of our eTwinning project were presented at the Greek Ministry of Education, at educational meetings, conferences and in the Press. The eTwinning music library, that was created includes theoretical texts and scholarly articles on music, Choral works by Greek and European composers, voice exercises, arias and scales mostly from Italian opera, traditional Greek music, chanting and traditional songs in braille, modern European composers and compositions by teachers, students and alumni of the school.

Original compositions such as songs for school events were produced, songs about the heroes of 1821, Kolokotronis, Karaiskakis, Papaflessas, Bouboulina, Athanasios Diakos and others, songs about the Macedonian Freedom Fighters of 1912, about Asia Minor and the Pontus region of the Black Sea, songs about peace and many others. Blind students participated (Figure 13).

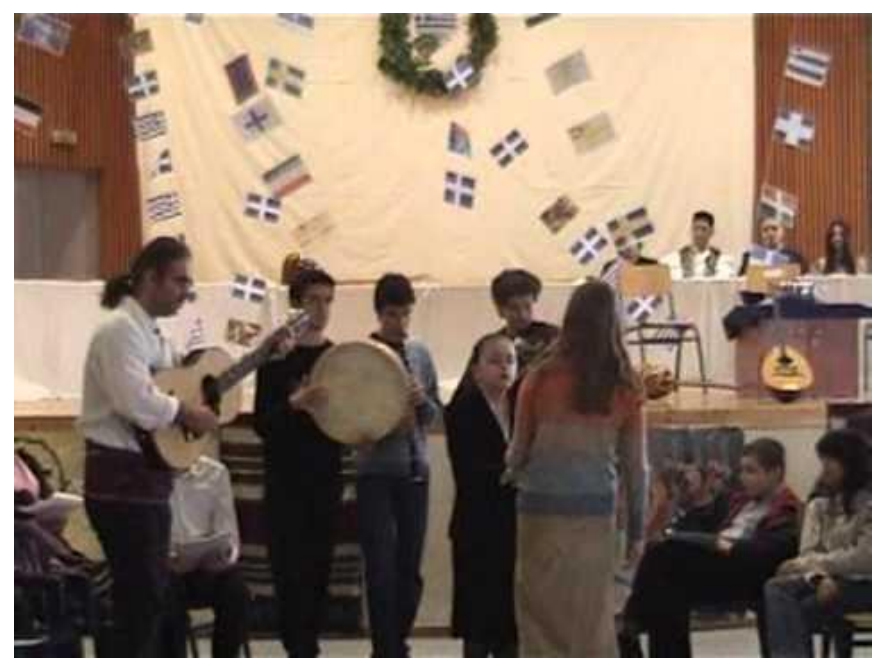

Figure 13: The song of Karaiskaki,

Music School of Thessaloniki, Music Library, 2005

Traditional songs were transcribed and new compositions were created based on traditional tunes (contemporary Asia Minor and Black Sea songs) Songs were adapted 
from a series of books by the distinguished writer Myrsini Vingopoulou and presented at the International Book festival of Thessaloniki.

The library was enriched by digital films, a) An educational documentary on DVD about the life of Saint Paul by students with impaired vision. A student with impaired vision chose photographs from the Internet and edited them on a computer. A blind student sang songs and hymns we composed about Saint Paul (Figure 14).

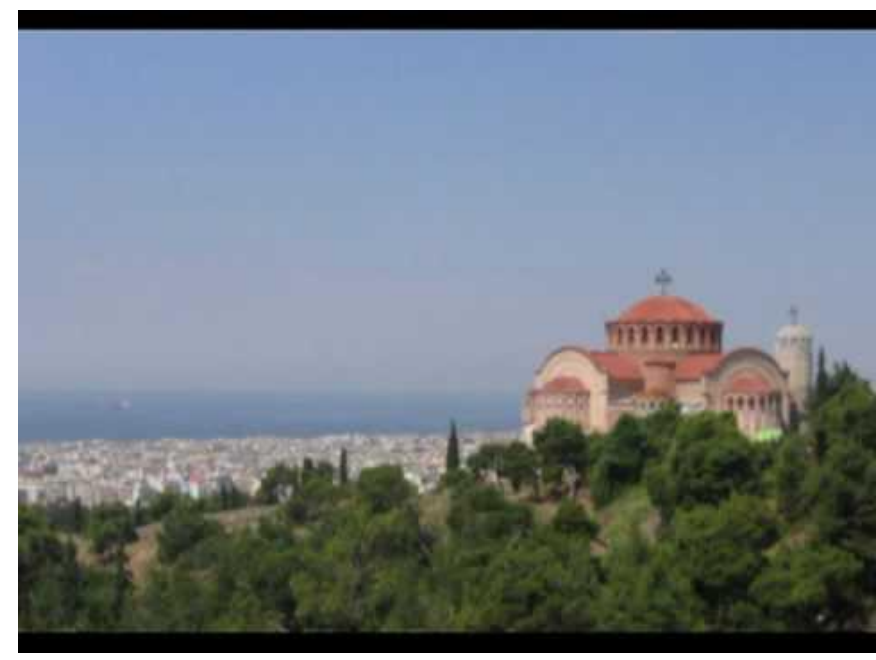

Figure 14: Educational documentary on DVD about the life of Saint Paul, Music Library, 2005

The students of the school also embarked on an innovative activity, producing a trilingual video The Pied Piper of Hamelin. The puppets were made in the UK, the music was composed by the Thessaloniki Music School, and the puppet performance took place in Italy (Figure 15).

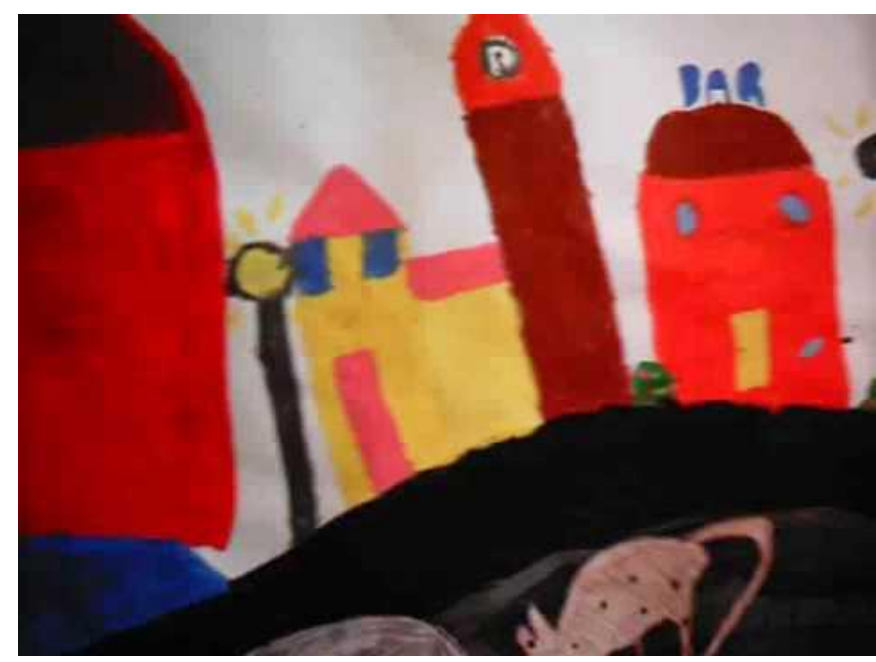

Figure 15: The Pied Piper of Hamelin, 2009

The students also created an educational DVD The Secret World of Icons, an analysis of the Icon of the Annunciation. It is worth noting that this was a big step towards the collaboration of students with special needs and students with pervasive developmental disorders. The students learned to work together and support each other. 
Students without visual impairments learned to transcribe music into braille form, for students with impaired vision, with amazing results. They used sign language at the performance of the composition. They used musical works presented in the form of power point with designs, pictures and sheet music created by students. This project had multiple benefits. Teachers and students worked together creatively. They planned and presented original and remarkable concerts and events. At the same time, they succeeded in their purpose which was to raise awareness of students about special education.

Students learned to work with school mates with special educational needs. They produced original compositions, and they learned to find, evaluate and edit information on the internet.

They became familiar with recording and editing music, and they also succeeded in forming networks with the Macedonia University Library and the Library of the Royal National Institute for the Blind in the UK.

We were asked to do a presentation of our project at a conference for Primary Schools in the East Thessaloniki Area, on new technology in Primary Education (2008), and at an educational event for the Regional Authority of Central Macedonia on the educational evaluation of innovative activities: eTwinning, Comenius, and teachers' initiatives.

This project for students with special educational needs was the catalyst for active, original and experiential learning, and it was given a national award for e Twinning in 2010 .

\section{4. eTwinning Hymn and the Creation of an Electronic eTwinning Orchestra}

Cultural Thessaloniki Music School with its workshops and musical ensembles found a multidimensional expression through the e Twinning collaboration: the creation of a digital library so that students can work on their digital technology in an interdisciplinary way, at choir practice, history, composition, harmony, hymnography and musical composition, and the students and teachers of the school composed an e Twinning Hymn: e Twinning is our project and a lovely destination, all we have to do is work together for an everlasting relation. Day and night I dream of e Twinning, the splendid thoughts of friendship. Our countries connect with sea, but our hearts connect e Twinning (Figure 16). 


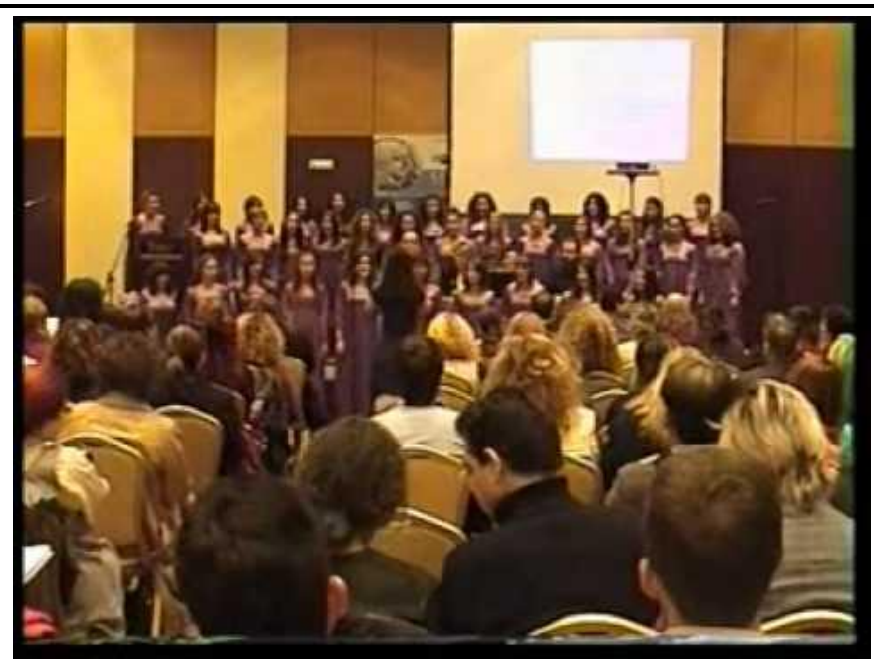

Figure 16: First presentation of eTwinning Hymn, Thessaloniki 2009

This hymn has to date been translated into several different languages and presented in different editions by 21 schools. Most important versions are by the Thessaloniki Music School choir under the direction of Angeliki Krisila with piano accompaniment, the children's choir from Southwater Infant School in the UK, with a percussion ensemble, a traditional performance on the banjo in Greece and Turkey, a performance on the church organ and choir in Ferrandina Italy (Figure 17).

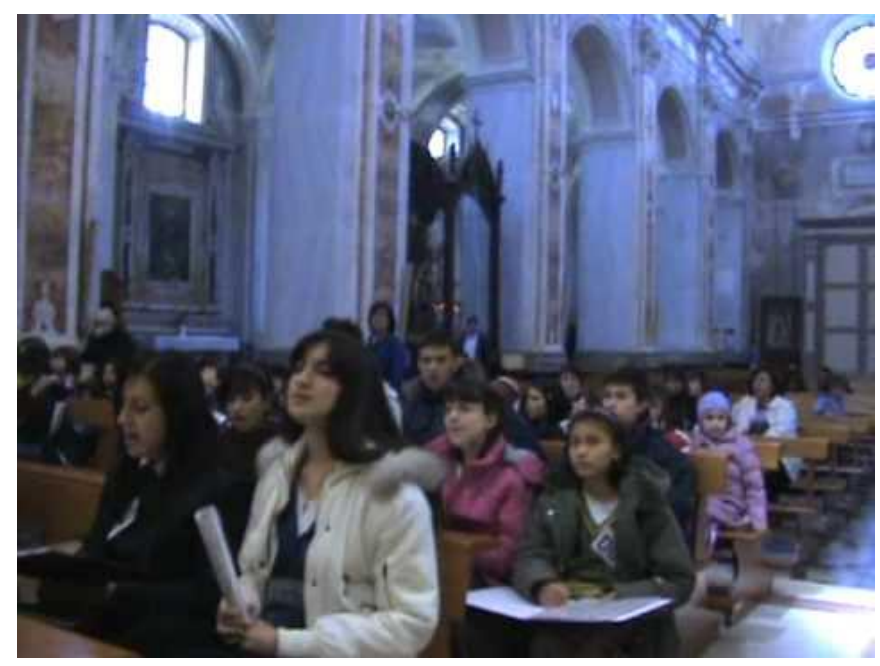

Figure 17: Etwinning Hymn played with an orgel in Ferrandina Church-Italy, 2010

The eTwinning Hymn was presented and as a soundtrack with simultaneous upload of the sheet music so that other schools can participate in the musical interpretation of the hymn (Tsampatzidis, 2010).

Students from the art department with their teacher Dimitris Tzovanakis designed a large poster with the colours of the flags of the different countries and students with special educational needs took part. The project was presented live at special events and conferences of innovative activities by the Central Macedonia Regional Authority Education Office and was referred at the Excellence and Innovation in Education awards. 
Parallel, the blog http://blog.eun.org/hymnoffriendship created a European dimension for the project. The hymn was the inspiration for an electronic e Twinning orchestra whose members will be from various schools, for example, a pianist from the UK, a flautist from Italy, a guitarist from Spain, soprano from Greece, bass singers from Ireland and so on. They will work together a) either through a multi channel digital recording with one school sending their recording to the others, or b) simultaneous performance through telematics.

\section{Special Presentations for Students with Learning Difficulties and Pervasive Developmental Disorders}

The project involves the creation of special music worksheets using computer software for students at the Thessaloniki Music School-Greece with pervasive developmental disorders and learning disabilities, like hyperactivity, dysgraphia, dyscalculia, and dysorthography. Special Power Point presentations were created so that it would be easy and accessible to teach music and other theoretical subjects to these students using new technology as much as possible in every lesson and at the same time maintaining contact online with the students' parents (Tsampatzidis, 2011b).

The special Power Point presentations were at first only for music, but through e Twinning, pilot programs with other lessons and other schools were begun. There was a combination of three special educational methods:

- Relationship Development Intervention (RDI),

- Irlen Method (Light Sensitivity),

- Treatment and Education of Autistic and Communication Handicapped Children (TEACCH method).

The Relationship Development Intervention is based on a method devised by the psychologist Dr Steven Gutstein aimed at improving social contacts and developing the personality, with step by step exercises to create incentives, so that skills can be used in the family environment and in social settings (Gutstein \& Sheely, 2002). This method helps to improve attention skills, to receive and process information, and the desire to look for and find peer relationships. This method is based on dynamic intelligence rather than static intelligence, which can only process information and remember events. Dynamic intelligence can give a flexible and dynamic approach to new situations. So R.D.I. tries to create dynamic intelligence working together and of course with the help of the family.

According to the Irlen method $70 \%$ of the information perceived is through sight, and it must be interpreted correctly by the brain. Any difficulty in processing this optical information may cause difficulty in the everyday ability to function normally (Irlen, 1991). Sensory overload can cause problems in the ability to interpret and interact in an everyday environment. Autism and Asperger syndrome are helped by the Irlen method which is for people with perceptual difficulties and oversensitivity to light, and the inability to filter light frequencies. Her method allows the brain to process visual 
information normally. Her method has been used in the USA for twenty five years to help people who have difficulty processing the information received from the eyes. The Irlen method successfully used colored backgrounds and lenses in over a hundred studies in education, psychology and medicine. There are over sixty published papers in reliable academic and scholarly papers on the efficacy of using colored lenses and backgrounds to assist perception related difficulties connected to information processing. Our innovative proposal uses the Irlen method for the background and presentation colors.

According to the TEACCH method, it is vital to understand the special cognitive features of people with autism and being able to adapt to the environment. Of course, our goal in special education is not to "normalize" young people with autism but to support them appropriately (Mesibov et al, 2004). Educational support is for life and is adapted to the level of difficulty that each person on the Autism spectrum has. This structured approach uses the findings of scholarly studies about the exceptionally good visual perception and thinking that people with Autism have. They also process sensory stimulation in unusual ways. Students with autism can only give partial attention to the lesson and they are unable to understand the full context of the information. The role of the teacher is to decode the expectations and norms of the non-autistic classroom so that students with autism can communicate more easily and successfully with non-autistic people. This means that the teacher must be able to understand the way that autistic students think to adapt the learning environment so that the student can learn to react in an independent way. Teaching with special visuals has been shown to be particularly successful for them to become independent. The structured approach and its application depends on a continuous and systematic evaluation which focuses on abilities, interests and emerging skills of people with autism. It is also very important to mention that the main purpose is not to look at the weaknesses of people with autism but to encourage them to prove their own abilities, which they can do with a little support. The information obtained from the interests of students with autism contributed to the design and development of educational material.

Collaboration with parents in this structured approach is of vital importance since parents are involved closely with the therapy and must be actively involved in their children's education, so that their child's skills can be used both at home and in their social world.

The presentations made on eTwinning used the following rules: various shades of red were used as a background, ranging from dark to light on the right hand side, to focus the students' attention (Figure 18). 


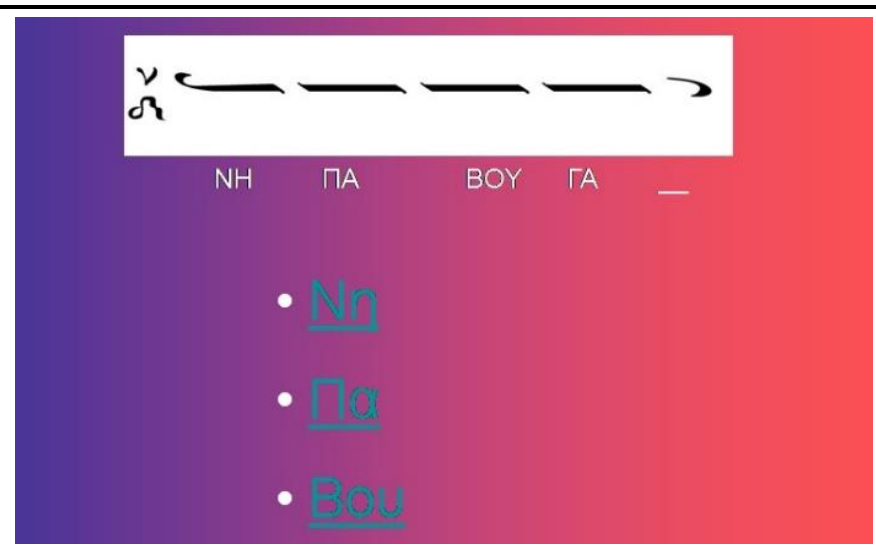

Figure 18: Example of a special music worksheets for students with pervasive developmental disorders learning Byzantine chant notation, 2012

The screen has no additional decorations, only the items that are necessary. Additionally, one or two of the student's favourite pictures from the particular subject can be added.

The first part of the presentation is the introduction. There is a brief theoretical part. The title appears first and then gradually each part. The letters are highlighted in turn. It is important to return to knowledge that has already been learned, starting with repetition and recalling primary concepts to mind.

The second part is a simple exercise which gives options like a puzzle. A wrong answer is immediately replaced with the right answer without any praise or criticism.

The third part of the presentation is question answer and multiple choice. You can choose between three answers. The true -false questions come at the end of the presentation because students with pervasive developmental disorders can focus better at the beginning of the teaching hour and in this way students' exhaustion is avoided. Each right answer is rewarded with the word on the screen with an appropriate sound. A wrong answer simply leads on to the next question. At the end of the presentation there is a highlighted word on the screen and the sound of applause. These presentations can be adapted for other subjects.

This project was awarded with a prize in 2011 for Excellence and Innovation in Education by the Greek Ministry of Education and Religious Affairs. In February 2012 the findings from these innovative activities were presented together at a European Grundtvig workshop on ICT and special Music Education at Thessaloniki Music School.

\section{Conflict of Interest Statement}

The author declares no conflicts of interests.

\section{About the Author}

Father Theodoros Tsampatzidis is music teacher at the Music School of Thessaloniki, Greece. He is also a doctoral candidate at the Music Department of Ionian University, Greece. His project researches focusing on teaching of music to students with special educational needs, visual impairment and diffused developmental disorders, and 
presents the use of new technologies. He is also Greek orthodox priest, music composer, choir conductor and has been awarded several times by the Greek Ministry of Education for innovative educational actions and European projects.

\section{References}

Baker, D., \& Green L. (2019). Insights in Sound Visually Impaired Musicians' Lives and Learning. London: Routledge

Baker, D., Fomukong-Boden, A., \& Edwards, S. (2019). 'Don't follow them, look at me!': Contemplating a haptic digital prototype to bridge the conductor and visually impaired performer. Music Education Research, 21(3), 295-314, Available online at https://doi.org/10.1080/14613808.2019.1605344

Braille Authority of North America, (2016). Music Braille Code. Kentucky: American Printing House for the Blind.

Chaldeakes, A. (2012). The (Greek-speaking) Instruction of the Psaltic Art. Past, Present and Future. Musicology Today, 12(4) (October-December 2012), 173-196.

Georgaki, A., Raptis, S., \& Bakamidis, S. (2000). A Music Interface for Visually Impaired People in the WEDELMUSIC Environment. Design and Architecture. Available online at http://scholar.uoa.gr/sites/default/files/georgaki/files/10. ismsir 2000.pdf.

Gutstein, S., \& Sheely, R. (2002). Relationship Development Intervention with Young Children. London: Jessica Kingsley Publications.

Heward, W. L., \& Orlansky, M.D. (1992). Exceptional children. An introductory survey of special education (Fourth Edition). New York: Macmillan Publishing Company.

Irlen, H. (1991) Reading by the colors: Overcoming dyslexia and other reading disabilities through the Irlen Method, N.Y, Avery Publishers.

Jenkins, E. (1060). Primer of Braille Music, Kentucky: American Printing House for the Blind.

Kersten, F. (1997). The History and Development of Braille Music Methodology. The Bulletin of Historical Research in Music Education, 18(2), 106-125. Available online at https://doi.org/10.1177/153660069701800202.

Kugelmass, J. A. (1954). Louis Braille. Windows for the blind. New York: Julian Messner, Inc., 1954.

Manitsa, I., \& Doikou, M. (2020). Social support for students with visual impairments in educational institutions: An integrative literature review. British Journal of Visual Impairment. Available online at https://doi.org/10.1177/0264619620941885.

Mesibov, G. B., Shea, V., \& Schopler, E. (2004). The TEACCH approach to Autism Spectrum Disorders. New York: Springer Science and Business Media.

Music Library. (2009). The Pied Piper of Hamelin [Video]. Available online at https://www.youtube.com/embed/b1Q6vlizXRk?feature=oembed 
Music Library. (2010). Etwinning hymn played with an orgel in Ferrandina Church [Video]. Available online at https://www.youtube.com/embed/7F53HkVv9pc?feature =oembed

Music School of Thessaloniki. (2005a). Song of Karaiskaki [Video]. Available online at https://www.youtube.com/embed/0hGKXO6Zn5U?start=24\&feature=oembed

Music School of Thessaloniki. (2005b). Educational documentary on DVD about the life of Saint Paul [Video]. Available online at https://www.youtube.com/ embed/fwvkC379T Q?feature=oembed

Music School of Thessaloniki. (2009). First presentation of eTwinning Hymn [Video]. Available online at https://www.youtube.com/embed/okhssyPdshY?feature= oembed

Paraskevaidis, D. (1982). The new notation of three teachers using Braille. Athens: Agia Skepi Monastery Kerateos.

Rodenberg, L. W. (1931). Musical Education of the Blind of France. Journal of Visual Impairment $\mathcal{E}$ Blindness, 25(2), 73-119. Available online at https://doi.org/10.1177/0145482X3102500203

Sacks, S. Z., \& Silberman, R. K. (2000). Social skills. In A.J. Koenig \& M.C. Holbrook (Eds.). Foundations of education. Vol. II, pp. 616 -652. New York: AFB Press.

Salisbury, R. (2008). Teaching Pupils with Visual Impairment: A Guide to Making the School Curriculum Accessible. New York: Routledge.

Saslaw, J. (2009). Teaching Blind: Methods for Teaching Music Theory to Visually Impaired Students. Society for Music Theory, Vol 15, (3 \& 4). Available online at https://mtosmt.org/issues/mto.09.15.3/mto.09.15.3.saslaw.html

Tsampatzidis, T. (2007). Ways of transcribing Byzantine notation to the Braille system, Gregorios Palamas, 90(817), 253-271. Thessaloniki.

Tsampatzidis, T. (2009). Creation of a digital Music Library with access for students with impaired vision. Available online at http://slideplayer.gr/slide/1898889/ and http://msth.gr/index.php/activities/european-programs/etwinning/35-etwinning$\underline{1}$

Tsampatzidis, T. (2010). My eTwinning projects: Music Library. Brussels: Voices of eTwinning. Available online at https://www.etwinning.net/en/pub/getinspired/testimonials/voices-of-etwinning-.htm

Tsampatzidis, T. (2012). Special Educational Needs and Music Education. Transcribing Byzantine chant music into Braille [Master Thesis, Middlesex University]. Available online at http://dx.doi.org/10.13140/RG.2.2.24130.50885

Tuersley-Dixon, L., \& Frederickson, N. (2016). Social inclusion of children with complex needs in mainstream: Does visibility and severity of disability matter? International Journal of Developmental Disabilities, 62(2), 89-97. Available online at https://doi.org/10.1179/2047387715Y.0000000011 
Creative Commons licensing terms

Authors will retain the copyright of their published articles agreeing that a Creative Commons Attribution 4.0 International License (CC BY 4.0) terms will be applied to their work. Under the terms of this license, no permission is required from the author(s) or publisher for members of the community to copy, distribute, transmit or adapt the article content, providing a proper, prominent and unambiguous attribution to the authors in a manner that makes clear that the materials are being reused under permission of a Creative Commons License. Views, opinions and conclusions expressed in this research article are views, opinions and conclusions of the author(s). Open Access Publishing Group and European Journal of Special Education Research shall not be responsible or answerable for any loss, damage or liability caused in relation to/arising out of conflict of interests, copyright violations and inappropriate or inaccurate use of any kind content related or integrated on the research work. All the published works are meeting the Open Access Publishing requirements and can be freely accessed, shared, modified, distributed and used in educational, commercial and non-commercial purposes under a Creative Commons Attribution 4.0 International License (CC BY 4.0). 